\title{
Pyrolysis Treatment Enables Safe Application of Sewage Sludge in Horticulture - Tracking Potentially Toxic Elements Through the Biochar-Soil-Plant System in Tomato
}

Samaneh Tahervand ( $\sim$ s.tahervand@yahoo.com )

Bu Ali Sina University

Mohsen Jalali

Bu-Ali Sina University: Bu Ali Sina University

\section{Wolfram Buss}

Australian National University College of Science: Australian National University

\section{Research Article}

Keywords: Pyrolysis, PTEs, Plant growth, Health risk index, Sequential extraction

Posted Date: June 17th, 2021

DOI: https://doi.org/10.21203/rs.3.rs-550236/v1

License: (c) (i) This work is licensed under a Creative Commons Attribution 4.0 International License. Read Full License

Version of Record: A version of this preprint was published at Waste and Biomass Valorization on August 29th, 2021. See the published version at https://doi.org/10.1007/s12649-021-01558-z. 


\section{Abstract}

Biochar production via pyrolysis is a promising option to be used for sewage sludge treatment. Here we investigated the uptake of potentially toxic elements (PTEs) from sewage sludge and its biochar $\left(450^{\circ} \mathrm{C}\right)$ into cherry tomato plants and its fruits in pot experiments $(2,5$ and $10 \%)$ to assess the health risks associated with fruit consumption. We further studied the ability of the PTE-rich amendments to immobilize PTEs already present in soil through spiking of soil ( $\mathrm{pH}$ 7.4) with $\mathrm{Cd}, \mathrm{Cu}$ and $\mathrm{Zn}$. Our findings suggest that tomato consumption is not a human health risk when grown in soil amended with sewage sludge and its biochar; in most treatments PTE uptake into fruits was similar to the control. Vegetative plant growth was highest in sewage sludge-amended soils. Yet 5 and 10\% biochar-amended soils significantly increased tomato fruit yield compared to untreated sewage sludge application (400-500\% higher than 10\% sewage sludge-amended soil) and significantly decreased fruit uptake of $\mathrm{Cu}$ and Zn. Importantly, biochar also significantly immobilized PTEs present in contaminated (spiked) soil. As expected, available (DTPA-extractable) PTE contents were typically lower in biochar-amended soil and sequential extraction indicated that the PTEs were predominantly bound in more recalcitrant soil fractions (organic matter associated and Fe-Mn oxides-bound). We conclude that pyrolysis can be a key technology for sewage sludge treatment and subsequent use of the biochar in urban, and potentially even contaminated, horticultural sites.

\section{Statement Of Novelty}

There are some studies on the sewage sludge and its biochar effect on potentially toxic elements (PTEs) behavior in soil-plant system. Yet, less well investigated is the uptake of PTEs into reproductive plant organs, which is of paramount importance for assessing the health risk associated with consumption of plant seeds and fruits. Also, little is known about the potential for immobilization of PTEs by biochar that already contains elevated levels of PTEs. The other novelty of this manuscript is to compare the bioavailability and fractionation of PTEs in spiked soil with non-spiked soils as influenced by sewage sludge and its biochar addition.

\section{Introduction}

The amount of sewage sludge (SS) produced globally from urban and industrial sources is increasing with the world's population and industrialization [1]. SS contains organic matter (OM), macro-nutrients ( $\mathrm{N}, \mathrm{P}$ and K), and micro-nutrients, and therefore has been applied on agricultural land as soil amendment and fertilizer for decades $[2,3]$. Unfortunately, it also contains contaminants, including potentially toxic elements (PTEs), pathogens and organic compounds, such as polycyclic aromatic hydrocarbons (PAHs) [4]. Therefore the application can pose a health risk for humans and the environment [5] and it is necessary to treat SS before soil application.

Pyrolysis is a technique that converts biomass under oxygen-limited condition into a material called biochar. The process reduces the volume of the material, sterilizes it and decomposes or removes organic contaminants [4, 6, 7]. Consequently, the application of SS biochar to agricultural land is of much less concern to the environment than the application of untreated SS $[8,9]$. Modifications of biomass material, such as potassium doping, produce biochar with nutrient-release properties beneficial for plant growth enabling agronomic use of SS biochar [10].

During pyrolysis, PTEs, such as cadmium (Cd), copper (Cu) and zinc (Zn) present in the biomass material are enriched in the biochar [11]. However, the availability, mobility, and leachability of PTEs are lower in biocharamended soils compared to SS-amended soils [12]. Pyrolysis reduces the environmental risk of PTE-rich biochar 
as a soil amendment compared to unpyrolysed material because it is more efficient in the sorption of cations and therefore reduces PTE release $[13,14]$. Yue et al. [15] reported that the total content of PTEs in soil increased following the application of biochar, yet a large amount of the added PTEs was assigned to a non-available PTE fraction.

The large amounts of SS available in urban centers and high concentrations of nutrients in sewage sludge biochar make it ideal for use in urban horticultural systems. The research is clear on the ability of pyrolysis to immobilize PTEs in SS [8, 10]. Tomato is the most important horticultural crop worldwide [16]. Therefore, in the first part of this experimental series, we focus on assessing the effects of SS biochar on tomato plants and tomato fruits.

Many urban centers are contaminated with PTEs $[17,18]$ and it is well-known that biochars and non-biochar organic materials, such as compost can sorb and immobilize PTEs in soil [19]. The ability to sorb PTEs and hence reduce PTE plant uptake would be an added benefit of SS biochar for the application in horticultural systems in urban areas. This could potentially enable the use of low-value, contaminated land for horticultural production close to human population centers. The key research questions for the second part of our experimental series are (i) is PTE-rich biochar able to sorb additional PTEs from soil and if so (ii) does this happens at the expense of PTEs already sorbed to biochar (subsequent release of biochar-inherent PTEs).

In this study, we investigate the effect of SS and SS-derived biochar (2, 5 and 10\%) on plant biomass and PTES uptake into vegetative and reproductive organs of tomato plants and subsequent health risk associated with consumption of tomato fruits. We performed experiments in both uncontaminated, low-PTE soil and soil spiked with Cd, Cu and Zn. Spiked soils were used to study sorption of PTEs present in soil by PTE-rich SS biochar and unpyrolysed SS. In addition, we assessed the DTPA-extractable PTE content in soil and their chemical fractionation in the rhizosphere and in the bulk soil. This aim was to track (i) inherent PTEs in SS biochar and (ii) PTEs present in contaminated soil through the biochar-soil-plant system.

\section{Material And Methods}

\subsection{Soil, sewage sludge, and biochar sampling and their properties}

An agricultural soil (within depth $0-30 \mathrm{~cm}$ ) was sampled from the Azandarian region located in the Hamedan province, Iran. The SS sample was collected from the municipal wastewater treatment plants in the Sanandaj province, Iran. Soil and SS samples were collected in 2018. The biochar sample was prepared from SS through slow pyrolysis at a temperature of $450{ }^{\circ} \mathrm{C}$ for $7 \mathrm{~h}$.

The soil, biochar and SS samples were analyzed by methods suggested by Rowell [20]. Electrical conductivity (EC) and $\mathrm{pH}$ were determined in deionized water with a soil-solution ratio of 1:5. The content of OM was measured by the dichromate oxidation procedure. Calcium carbonates equivalent (CCE) was determined by the acid neutralization method. Determination of cation exchange capacity (CEC) was done by a neutral $1.0 \mathrm{M} \mathrm{NH}_{4} \mathrm{OAc}^{-}$ saturation method. Dithionite-citrate-bicarbonate Fe $\left(\mathrm{Fe}_{\mathrm{d}}\right)$ was measured by the method given by Mehra and Jackson [21]. The surface structure of SS and biochar was analyzed by JSM-840A scanning electron microscopy (SEM). Fourier transform infrared (FTIR) spectrum of SS and biochar was used to determine the chemical functional groups by a Perkin-Elmer FTIR spectrometer 17,259 using KBr disks.

\subsection{Greenhouse experiment}


The pot experiment was designed for untreated, control (C) and spiked soils (S). For preparing the spiked soils, the PTE amounts equivalent to 10, 250, and $400 \mathrm{mg} \mathrm{kg}^{-1}$ of cadmium (Cd), copper (Cu), and zinc (Zn), respectively, were added to the soil by using chloride salts. These contents were selected based on the average values of regulatory standards of PTEs in agricultural soil reported by He et al. [22]. The non-spiked (control soil) and spiked soils were incubated at field moisture for three weeks. Finally, the SS or biochar was mixed with the soils at rate of $0 \%, 2 \%, 5 \%$ and $10 \%$ on a dry weight basis. After the incubation period, cherry tomato (Lycopersicon esculentum L.) seeds were sown in peat moss and perlite combination placed in multiple-cell containers. After emergence about 14 days after sowing, one cherry tomato was planted in each of the pot ( $2 \mathrm{~kg}$ of soil each). The experiment was conducted in three replicates in a glass house at temperatures of $20-30{ }^{\circ} \mathrm{C}$. The period of experiment was three months (from December 2018 to March 2019). The pots were irrigated with deionized water approximately up to field capacity.

Rhizosphere and bulk soil samples were separated by pulling plants out of the soil and gently shaking them by hand at the end of the greenhouse experiment. The soil that remained on the roots was regarded as the rhizosphere soil, and the soil that separated from the roots was considered as the bulk soil [23]. Then rhizosphere or bulk samples were air-dried and thoroughly mixed for analysis.

\subsection{Plant analysis}

The fresh weight of each part (root, shoot, and fruit) was measured. Then, samples were placed in an oven at 70 ${ }^{\circ} \mathrm{C}$ for $48 \mathrm{~h}$ and the dry weight of each portion was taken. The PTE content in plants was measured via the $\mathrm{HNO}_{3} / \mathrm{H}_{2} \mathrm{O}_{2}$ wet digestion method given by Cao et al. [24]. Firstly, $0.3 \mathrm{~g}$ of the plant samples was placed in a Teflon container. Then, $5 \mathrm{~mL}$ of concentrated nitric was added and the samples were left overnight. The next day, 2 $\mathrm{ml} \mathrm{H}_{2} \mathrm{O}_{2}$ was added and samples were placed in a microwave digester until the mixture became clear. The aliquots collected in the bottle diluted to a final volume of $25 \mathrm{ml}$ with deionized water. At the end of the digestion period, PTE content in roots, shoots, and fruits was analyzed by atomic absorption spectrophotometry (AAS).

\subsection{Bioconcentration factor}

The bioconcentration factor (BCF) was calculated as the ratio of PTE content in plant tissues ( $\mathrm{mg} \mathrm{kg}^{-1}$ ) at harvest and the content of total PTEs in soil $\left(\mathrm{mg} \mathrm{kg}^{-1}\right)$ [25]. This factor was determined for the root $\left(\mathrm{BCF}_{\text {root }}\right)$, shoot $\left(\mathrm{BCF}_{\text {shoot }}\right)$, and fruit $\left(\mathrm{BCF}_{\text {fruit }}\right)$ of the plant.

\subsection{Human health risk assessment}

Estimated daily intake (EDI) ( $\mathrm{mg} \mathrm{kg}^{-1}$ day $^{-1}$ ) and health risk index (HRI) of PTEs via cherry tomato consumption was calculated as follows [26, 27]:

$$
\begin{aligned}
& \mathrm{EDI}=\frac{\mathrm{F}_{\mathrm{IR}} \times \mathrm{C}}{\mathrm{W}} \\
& \mathrm{HRI}=\frac{\mathrm{EDI}}{\mathrm{ORD}}
\end{aligned}
$$


where $F_{I R}$ is the daily vegetable consumption of $109.0 \mathrm{~g}$ per person and day [28], $C$ is the PTE content in the fresh weight of cherry tomato fruits $\left(\mathrm{mg} \mathrm{kg}^{-1}\right), \mathrm{W}$ is the average body weight of $70.7 \mathrm{~kg}$ adult and $32.9 \mathrm{~kg}$ children [27], ORD is the oral reference dose and the values of $0.001,0.04$ and $0.30 \mathrm{mg}^{-1} \mathrm{~kg}^{-1}$ day-1 were considered for $\mathrm{Cd}, \mathrm{Cu}$, and $\mathrm{Zn}$, respectively [29].

If the EDI of PTEs exceeds the ORD, the HRI becomes $\geq 1.0$, and human is exposed to a level of contamination with potential adverse health effects [30].

\subsection{Determination of total and DTPA-extractable PTEs}

Total PTEs contents in the soil, SS, and biochar were determined via the procedure proposed by Pietrzak and McPhail [31]. To determine the total PTEs content, $2 \mathrm{~g}$ of each sample was weighed into $50 \mathrm{ml}$ tubes and $2.5 \mathrm{ml}$ of $70 \mathrm{wt}$ \% of $\mathrm{HNO}_{3}$ was added. The samples were left overnight to digest at room temperature. The next day, $7.5 \mathrm{ml}$ of $70 \mathrm{wt} . \% \mathrm{HNO}_{3}$ was added to each tube and the mixtures were placed in a boiling water bath. Samples were digested at $100{ }^{\circ} \mathrm{C}$ for $8 \mathrm{~h}$. After this time, samples were centrifuged for $3 \mathrm{~min}$ at $3500 \mathrm{rpm}$, and the supernatant was filtered into $50 \mathrm{ml}$ volumetric flasks. The residual wet solid was rinsed with $10 \mathrm{ml}$ and then with $5 \mathrm{ml}$ of deionized water, centrifuged and the aliquots added into the $50 \mathrm{ml}$ volumetric flask. Finally, PTE concentrations were analyzed by AAS.

Analysis of DTPA-extractable PTEs was carried out by the method suggested by Lindsay and Norvell [32].

\subsection{Sequential extraction}

The sequential extraction of PTEs was performed using the procedure suggested by Tessier et al. [33] which was modified by Jaradat et al. [34]. In this procedure, PTEs were classified into solution and exchangeable (F1; EXCH), bound to carbonate phase (F2; CARB), bound to iron and manganese oxides (F3; Fe-Mn OX), bound to organic matter and sulfides (F4; OM), and residual (F5; RES).

The mobility factor (MF) of PTEs was determined for the samples by equation 3 [35]. The units of MF and F1 to $\mathrm{F} 5$ are $\%$ and $\mathrm{mg} \mathrm{kg}^{-1}$, respectively.

$$
\mathrm{MF}=\frac{\mathrm{F} 1+\mathrm{F} 2}{\mathrm{~F} 1+\mathrm{F} 2+\mathrm{F} 3+\mathrm{F} 4+\mathrm{F} 5} \times 100
$$

As a check on the values from the sequential method, the sum of the five fractions $\left(\mathrm{F} 1+\mathrm{F} 2+\mathrm{F} 3+\mathrm{F} 4+\mathrm{F} 5\right.$ in $\left.\mathrm{mg} \mathrm{kg}^{-1}\right)$ and the total content of PTEs ( $\mathrm{TC}$ in $\mathrm{mg} \mathrm{kg}^{-1}$ ) determined by concentrated nitric acid was compared in the recovery rate ( $\mathrm{R}$ in \%) equation:

$$
\mathrm{R}=\frac{\mathrm{F} 1+\mathrm{F} 2+\mathrm{F} 3+\mathrm{F} 4+\mathrm{F} 5}{\mathrm{TC}} \times 100
$$

\subsection{Quality control of data and statistical analysis}


To validate the analytical method, certified reference salts (Merck, Darmstadt, Germany) for each PTE were used to spike the soil. All experiments were carried out in triplicate and a blank sample was applied for each measurement. The instruments were calibrated by standard solutions before each measurement. The detection limits of AAS for $\mathrm{Cd}, \mathrm{Cu}$, and $\mathrm{Zn}$ were $0.02,0.03$, and $0.01 \mathrm{mg} \mathrm{l}^{-1}$. After the incubation period of soil spiking with Cd, $\mathrm{Cu}$, and $\mathrm{Zn}$ salts, the average total PTEs recovery percentages of $\mathrm{Cd}$, $\mathrm{Cu}$, and $\mathrm{Zn}$ for spiked soils were 92.8, 95.0, and 93.7, respectively.

Statistical analyses using a significant level of $p<0.05$ were carried out using SAS [36]. One-way ANOVAs followed by Duncan's multiple range post-hoc test were applied to identify significant differences among treatments for data on bioavailability, fractionations, and uptake of PTEs. The experimental design was completely randomized with three replicates. Correlations between PTE contents in plants and extraction from soil were determined using Pearson's correlation analysis.

\section{Results}

\subsection{Properties of soil, sewage sludge and biochar}

The biochar yield of SS pyrolysed at $450^{\circ} \mathrm{C}$ was approximately $70 \%$. Conversion of SS to biochar increased the $\mathrm{pH}$ from 6.4 to 6.6, and decreased CEC, OM, and EC from 43.7 to $5.0 \mathrm{cmol}_{\mathrm{C}} \mathrm{kg}^{-1}, 29.4$ to $12.1 \%$, and 2.50 to $1.71 \mathrm{dS} \mathrm{m}$

1 , respectively (Table 1$)$. The pyrolysis process increased total PTE content by: Cd $(\times 1.2), \mathrm{Cu}(\times 1.1)$ and $\mathrm{Zn}(\times 1.3)$, but decreased DTPA-extractable PTEs by: $\mathrm{Cd}(\times 8.7), \mathrm{Cu}(\times 115.5)$, and $\mathrm{Zn}(\times 7.2)($ Table 1$)$. This behavior is well documented in the literature, for SS and other biomass $[11,37,38]$.

The surface of SS was mostly compact and the pore structure negligible demonstrated by SEM, whereas biochar had a porous surface (Fig. A.1). FTIR analyses identified a peak at $3341 \mathrm{~cm}^{-1}$ and peaks at 2925 and $2851 \mathrm{~cm}^{-1}$ in the SS sample that can be assigned to hydroxyl groups and aliphatic structures, respectively (Fig. A.2). These peaks decreased in the biochar sample, as also observed by Hossain et al. [37] and Song et al. [39] who suggested the decomposition of aliphatic $\mathrm{C}-\mathrm{H}$ bonds at $450^{\circ} \mathrm{C}$. The peaks showed at 1658 and $1548 \mathrm{~cm}^{-1}$ were caused by $\mathrm{C} \bowtie \mathrm{O}$ and $\mathrm{C} \varangle \mathrm{C}$ functional groups, which also decreased after pyrolysis. Peaks at 1030 and $875 \mathrm{~cm}^{-1}$ were less affected by the pyrolysis treatment and are likely $\mathrm{Si}-\mathrm{O}$ (quartz) / $\mathrm{C}-\mathrm{O}$ bonds [39] and $\mathrm{CaCO}_{3}$, respectively (Fig. A.2).

\subsection{Plant biomass}

The dry weight of roots and shoots increased with amendments of both unpyrolysed SS and biochar (in nonspiked soil; Fig. 1a). The highest root and shoot dry weights were observed in the 2 and 5\% SS-amended soils, followed by the $10 \%$ biochar-amended soil. The highest application rate of SS led to stunting of plant growth, while the highest application rate of biochar enhanced plant growth. These results are in the line with data on tomato (Solanum lycopersicum) published by Waqas et al. [40].

The highest fruit dry weights were observed in 2\% SS-amended, and 5 and $10 \%$ biochar-amended soils with values 2.4, 3.0 and 3.6 times higher than the control (Fig. 1a). Hossain et al. [41] reported that in their study fruit dry weight for biochar-amended soils was $64 \%$ and $21 \%$ higher than the control and SS amended soil, respectively. 
Plants grown in the soils that received extra PTEs (spiking with $\mathrm{Cd}$, Cu and Zn) were severely negatively affected (Fig. 1b). Application of SS in addition to spiking of soil with PTEs completely inhibited plant growth. Biochar addition, on the other hand, resulted in plant growth similar to the control. In the $10 \%$ biochar-amended soil root and shoot dry weight was even significantly increased compared to the control. Remarkably, the $10 \%$ biochar amendment was the only treatment in the spiked soil (including the control treatment) that demonstrated fruit yield (Fig. 1b).

\subsection{Potentially toxic elements contents in plant tissue}

As expected, the roots demonstrate the highest bioconcentration factors (BCFs) due to an exclusion strategy that constraints transport of PTEs from the root towards shoot and fruit [42]. In the non-spiked soil, the aboveground plant tissue concentration of Cd only changed marginally with SS and biochar amendments (Fig. 2a). Yet, Cd concentrations in the root (non-spiked soil) were significantly higher in the amended treatments compared to the control soil (Fig. 2a; Table 2). Furthermore, the contents of Cd in the shoot of $10 \%$ SS-amended soil (and BCF in the shoot) and in the fruit of 2 and $10 \%$ biochar-amended soils were significantly higher than the control and the other non-spiked treatments. Importantly, the addition of biochar to spiked soil reduced the content of Cd in the root and shoot (Fig. 2b) and $\mathrm{BCF}_{\text {root }}$ and $\mathrm{BCF}_{\text {shoot }}$ (Table 2).

Biochar application to non-spiked soils reduced the concentrations of $\mathrm{Cu}$ in shoot and fruit compared to the SS treatments considerably (Fig. 2c). While $2 \%$ and $5 \%$ biochar increased the concentration of $\mathrm{Cu}$ in the root tissue compared to all other samples, the concentrations in the $10 \%$ biochar treatment were the same as in the control. The $10 \%$ biochar-amended soil also demonstrated the lowest values for $\mathrm{BCF}_{\text {root }}, \mathrm{BCF}_{\text {shoot }}$ and $\mathrm{BCF}_{\text {fruit }}$ of all the treatments (Table 2). In the spiked soil, biochar did not change the concentration of $\mathrm{Cu}$ in the shoots, but the root concentration increased (Fig. 2d).

The shoot and root Zn concentrations did not demonstrate a consistent response with SS and biochar application in non-spiked soil, yet both tended to increase compared to the control (Fig. 2e; Table 2). The Zn contents in the fruit were significantly greater in the presence of SS compared to biochar (Fig. 2e) and the values of $\mathrm{BCF}_{\text {fruit }}$ decreased significantly in 5 and 10\% biochar-amended treatments as compared to control (Table 2). In the spiked treatments, $5 \%$ biochar also significantly decreased the root and shoot concentration compared to the control (Fig. 2f). Additionally, the values of $\mathrm{BCF}_{\text {root }}$ decreased significantly following the addition of biochar at the rates of 5 and $10 \%$ and the values of $\mathrm{BCF}_{\text {shoot }}$ decreased significantly following the $5 \%$ application of biochar (Table 2 ).

The estimated daily intake (EDI) of PTEs through cherry tomato consumption was in the order of $\mathrm{Zn}>\mathrm{Cu}>\mathrm{Cd}$. Despite the observed EDI order, the health risk index (HRI) of $\mathrm{Cd}$ for both adults and children were greater than for $\mathrm{Cu}$ and $\mathrm{Zn}$ (Table 3). This was because some values of EDI for Cd exceeded recommended oral reference dose (ORD) value, thereby causing higher HRI values. In a study by Pajević et al. [30], tomato was one of the top three vegetables with elevated levels of $\mathrm{Cd}$ and respective HRIs. Yet, in our study, all HRI values of $\mathrm{Cd}, \mathrm{Cu}$ and $\mathrm{Zn}$ via cherry tomato consumption were below 1 , indicating levels of contamination that do not pose a human health risk (Table 3). These values are in line with observations reported by Jalali and Karimi Mojahed [27] who also demonstrated that all HRI values of $\mathrm{Cd}, \mathrm{Cu}$ and $\mathrm{Zn}$ in cherry tomato do not pose a risk for adults and children.

\subsection{Potentially toxic elements extractability and fractions}


Overall, the addition of SS and biochar to non-spiked soils increased DTPA-extractable PTE contents as compared to the control soil (Fig. 3). This was confirmed in the fractionation assay where the residue PTE fraction decreased with all amendments in favor of more extractable PTE fractions (Fig. 4).

There is a linear increase in DTPA-extractable PTE concentrations with SS addition (non-spiked soils), clearly showing that SS adds available PTEs to soil. In contrast, biochar application only increased DTPA-extractable PTEs marginally in the $\mathrm{Cd}$ sample and there is no linear relationship of extractable $\mathrm{Cu}$ with biochar application rate. Overall, the DTPA-extractable concentrations of PTEs in SS amended soil and untreated SS (non-spiked soils) are significantly lower than in biochar and biochar-amended soil despite a higher concentration of total PTEs in biochar (Fig. 3; Table 1).

This result is less obvious in the fractionation assay (Fig. 4) where both amendments shift the proportions depending on type of PTE. Incorporation of SS and biochar into the non-spiked and spiked soils increased the CARB fraction of $\mathrm{Cd}$ compared to the control (Fig. 4a and b). This could be attributed to the high content of $\mathrm{CaCO}_{3}$ in SS (10.4\%) and biochar (10.7\%) (Table 1) and the ability of $\mathrm{CaCO}_{3}$ to decrease Cd activity in solution [43]. For all three PTEs, $10 \%$ SS and the biochar amendments increased PTE bound to OM. While the Fe-Mn oxide storage of $\mathrm{Cu}$ decreased with most amendment (Fig. 4c), it increased for Zn (Fig. 4e).

In the spiked soils, the added PTEs increased EXCH (Cd and Zn), CARB (Cu and Zn) and Fe-Mn OX fraction (Cd, Cu and Zn) over the non-spiked soils (Fig. 4). The DTPA-extractable PTE concentration in spiked soils increased more than 100-fold in comparison to non-spiked soils (Fig. 3). Importantly, the DTPA-extractable PTE concentration decreased with biochar application rate (Fig. 3b, $d$ and f). This is also the case for Cd and Zn in SS-amended soils, yet to a lesser extent (Fig $3 b$ and $\mathrm{f}$ ). Distribution of PTEs in the OM fraction increased with amendments, in particular for $\mathrm{Cu}$.

To compare the availability of PTEs, mobility factor (MF) based on data from the sequential extraction (see materials and methods) were calculated (Fig. A.3). Cd showed the highest MF in all treatments, as was reported by Bogusz and Oleszczuk [44] who investigated the distribution of PTEs in SS-amended soil. The MF values of PTEs followed the order of $\mathrm{Cd}>\mathrm{Zn}>\mathrm{Cu}$ (Fig. A.3). As expected, MF values in spiked treatments were greater than nonspiked treatments.

The DTPA-extractable concentrations of PTEs in the rhizosphere and bulk soil were comparable in most treatments (Fig. 3). Yet, for the non-spiked treatments, DTPA-extractable $\mathrm{Cu}$ at all rates of biochar application was significantly higher in the rhizosphere than that in the bulk soil sample (Fig. 3c). We correlated uptake of PTEs in aboveground plant tissue with DTPA-extractable concentrations and the sequential extraction assay (Table A.1). Unsurprisingly, the DTPA-extraction correlated best with all three PTEs in the non-spiked soil and less well with the artificial, spiked soils. Within the fractionation assay, Zn was predicted best, followed by Cu. Yet, for example the rhizosphere $\mathrm{Cu}$ concentration increased with biochar application rate, but the root tissue concentration dropped significantly at the highest biochar application rate to half of the value for $5 \%$ biochar (Fig 2c). Similarly, the Zn tissue concentration was significantly higher in the 5\% biochar-amended treatment and dropped in the $10 \%$ biochar-treatment (Fig. 2e), but the DTPA-extractable concentration consistently increased with biochar application rate (Fig. 3e). This clearly highlights that the root concentrations are weakly predicted by DTPAextractions and that extractions as predictors for plant uptake only go so far. Direct measurement of concentrations in different tissues are the best way for determining plant uptake and for understand the underlying mechanisms. 


\section{Discussion}

The application of SS at a low rate efficiently increased vegetative plant growth (shoot and root dry weight) of cherry tomatoes, whereas the addition of biochar at the high rate was more effective in increasing reproductive growth (fruit dry weight). Higher concentrations of available nitrogen $(\mathrm{N})$ and phosphorous $(\mathrm{P})$ as present in SS, on one hand, stimulate vegetative plant growth [10,37]. On the other hand, the ratios of nutrient levels seem more important for growth of fruits in tomato plants [45] and hence our biochar likely had a more suitable nutrient balance. Remarkably, in the spiked soil, where $\mathrm{Cd}$, $\mathrm{Cu}$ and $\mathrm{Zn}$ was added, $10 \%$ biochar application increased root and shoot growth compared to the control and enabled tomato fruit formation (no fruits in the control).

During pyrolysis PTEs are concentrated in biochar, yet the PTEs are less extractable as confirmed in various studies [e.g. 10,46]. This resulted in lower uptake of PTEs in the aboveground plant part in our study, hence lower BCF and reduced EDI compared to unpyrolysed SS, as also reported by Waqas et al. [40]. We can conclude that the rate of uptake of PTEs into tomato fruit does not cause any health concerns, answering our first research question.

Compared to unpyrolysed SS, the PTEs within biochar were preferably bound in more recalcitrant form, in association with $\mathrm{OM}(\mathrm{Cd}, \mathrm{Cu}$ and $\mathrm{Zn})$ and Fe-Mn oxides ( $\mathrm{Zn})$. The observed preference of $\mathrm{Cu}$ for $\mathrm{OM}$ and, $\mathrm{Zn}$ for Fe$\mathrm{Mn}$ oxides in this study agrees with Ignatowicz [47] and Huang et al. [48], who analyzed biochars by combining synchrotron X-ray spectroscopy/microscopy analysis and sequential chemical extraction. They report that $\mathrm{Cu}$ and $\mathrm{Zn}$ were desulfurized following the pyrolysis of SS, resulting in $\mathrm{Cu}-\mathrm{OM}$ association and $\mathrm{Zn}$ association with $\mathrm{Fe}$ minerals. Yuan et al. [49] suggests that the pyrolysis process reduces DTPA-extractable PTEs because of its large specific surface area, pore structure, and the formation of the organometallic complex. In particular pyrolysis at relatively low pyrolysis temperature, such as the $450^{\circ} \mathrm{C}$ performed here, enables PTE immobilization due to the retention of stable functional groups, while producing micropores and a rough surface area [39].

After soil spiking with $\mathrm{Cd}, \mathrm{Cu}$ and $\mathrm{Zn}$, biochar was able to reduce the extractable concentrations of all three PTEs. It actively immobilized $\mathrm{Cd}$ and $\mathrm{Zn}$ present in spiked soil by reducing the $\mathrm{EXCH}$ fraction, binding to Fe-Mn OX and CARB instead, which reduced plant Cd uptake in all plant parts. This is remarkable considering the relatively high concentrations of PTEs present in SS biochar and demonstrates the value of SS biochar in remediation of PTE contaminated soil. This effect cannot be attributed to an increase in $\mathrm{pH}$, which has been suggested as one of the main mechanisms of PTE immobilization by biochar, since the soil $\mathrm{pH}$ was higher than the biochar $\mathrm{pH}$. This phenomenon was recently documented [50]. Yue et al. [15] pointed out that the precipitation of PTEs by inorganic components of biochar, including carbonates, oxides, and phosphates contributes to the increase of pertinent fractions of PTEs in the biochar-amended soil. The formation of strong metal-organic complexes decreases the mobility of PTEs considerably [47].

Biochar did not release any $\mathrm{Cd}, \mathrm{Cu}$ and $\mathrm{Zn}$ in spiked soil, the opposite was the case, it was able to sorb additional PTEs. This answers our second research question: PTE-rich biochar can sorb additional PTEs and when doing so it does not release biochar-inherent PTEs, which highlights that the biochar sorption sites are not saturated with PTEs. This also gives higher confidence in biochar to retain its inherent PTEs on long-term when applied in noncontaminated soil. This ability could enable the use of SS biochar on low-value, urban land for horticultural production.

\section{Conclusion}


Pyrolysis converts SS into a material with low potential for PTE release and stabilizes the carbon within SS. Here we demonstrated that SS biochar can increase tomato yield compared to unpyrolysed SS despite resulting in lower vegetative plant biomass. It can also immobilize PTEs in spiked soil without releasing biochar-inherent PTEs. It highlights the value of pyrolysis for treatment of (PTE-rich) SS and subsequent use of the produced biochar in horticultural systems. Establishment of horticultural production in urban centers using sewage sludge biochar could close the nutrient loop locally. The process also sequesters carbon that would otherwise be released back into the atmosphere giving further environmental benefits.

\section{Declarations}

Acknowledgement We thank the University of Bu-Ali Sina for providing support for this study.

Authors' contributions ST: laboratory analyses, writing original draft. MJ: writing, review and editing. WB: writing, review and editing. All authors read and approved the final manuscript.

Data Availability All data generated or analysed during this study are included in this article [and its supplementary information files]. Detailed data can be made available from the corresponding author upon request.

Conflict of interest The authors declare that they have no conflict of interest.

Ethical approval This article does not contain any studies with human participants or animals performed by any of the authors.

Consent to participate No personal data are contained in this study that would require to ask for consent.

Consent to publish All co-authors have consented to the publication of this study.

\section{References}

1. Gao, N., Kamran, K., Quan, C., Williams, P.T.: Thermochemical conversion of sewage sludge: A critical review. Prog. Energy Combust. Sci. 79, 100843 (2020)

2. Urbaniak, M., Wyrwicka, A., Tołoczko, W., Serwecińska, L., Zieliński, M.: The effect of sewage sludge application on soil properties and willow (Salix sp.) cultivation. Sci. Total Environ. 586, 66-75 (2017)

3. Racek, J., Sevcik, J., Chorazy, T., Kucerik, J., Hlavinek, P.: Biochar - recovery material from pyrolysis of sewage sludge: A review. Waste Biomass Valorization. 11, 3677-3709 (2019)

4. Zielińska, A., Oleszczuk, P.: The conversion of sewage sludge into biochar reduces polycyclic aromatic hydrocarbon content and ecotoxicity but increases trace metal content. Biomass Bioenergy. 75, 235-244 (2015)

5. Kominko, H., Gorazda, K., Wzorek, Z.: The possibility of organo-mineral fertilizer production from sewage sludge. Waste Biomass Valorization. 8, 1781-1791 (2017)

6. Ross, J.J., Zitomer, D.H., Miller, T.R., Weirich, C.A., McNamara, P.J.: Emerging investigators series: Pyrolysis removes common microconstituents triclocarban, triclosan, and nonylphenol from biosolids. Environ. Sci. Water Res. Technol. 2, 282-289 (2016) 
7. Hoffman, T.C., Zitomer, D.H., McNamara, P.J.: Pyrolysis of wastewater biosolids significantly reduces estrogenicity. J. Hazard. Mater. 317, 579-584 (2016)

8. Roberts, D.A., Cole, A.J., Whelan, A., de Nys, R., Paul, N.A.: Slow pyrolysis enhances the recovery and reuse of phosphorus and reduces metal leaching from biosolids. Waste Manage. 64, 133-139 (2017)

9. Frišták, V., Pipíška, M., Soja, G.: Pyrolysis treatment of sewage sludge: A promising way to produce phosphorus fertilizer. J. Clean Prod. 172, 1772-1778 (2018)

10. Buss, W., Bogush, A., Ignatyev, K., Mašek, O.: Unlocking the Fertilizer Potential of Waste-Derived Biochar. ACS Sustain. Chem. Eng. 8, 12295-12303 (2020)

11. Buss, W., Graham, M.C., Shepherd, J.G., Mašek, O.: Suitability of marginal biomass-derived biochars for soil amendment. Sci. Total Environ. 547, 314-322 (2016)

12. Méndez, A., Gómez, A., Paz-Ferreiro, J., Gascó, G.: Effects of sewage sludge biochar on plant metal availability after application to a Mediterranean soil. Chemosphere. 89, 1354-1359 (2012)

13. Agrafioti, E., Bouras, G., Kalderis, D., Diamadopoulos, E.: Biochar production by sewage sludge pyrolysis. J Anal. Appl. Pyrolysis. 101, 72-78 (2013)

14. Jin, J., Li, Y., Zhang, J., Wu, S., Cao, Y., Liang, P., Zhang, J., Wong, M.H., Wang, M., Shan, S., Christie, P.: Influence of pyrolysis temperature on properties and environ-mental safety of heavy metals in biochars derived from municipal sewage sludge. J. Hazard. Mater. 320, 417-426 (2016)

15. Yue, Y., Cui, L., Lin, Q., Li, G., Zhao, X.: Efficiency of sewage sludge biochar in improving urban soil properties and promoting grass growth. Chemosphere. 173, 551-556 (2017)

16. Schwarz, D., Thompson, A.J., Kläring, H.P.: Guidelines to use tomato in experiments with a controlled environment. Front. Plant Sci. 5, 625 (2014)

17. Yu, K., Van Geel, M., Ceulemans, T., Geerts, W., Ramos, M.M., Serafim, C., Sousa, N., Castro, P.M.L., Kastendeuch, P., Najjar, G., Ameglio, T., Ngao, J., Saudreau, M., Honnay, O., Somers, B.: Vegetation reflectance spectroscopy for biomonitoring of heavy metal pollution in urban soils. Environ. Pollut. 243, 1912-1922 (2018)

18. Yuan, X., Xue, N., Han, Z.: A meta-analysis of heavy metals pollution in farmland and urban soils in China over the past 20 years. J. Environ. Sci. 101, 217-226 (2021)

19. Beesley, L., Moreno-Jiménez, E., Gomez-Eyles, J.L.: Effects of biochar and greenwaste compost amendments on mobility, bioavailability and toxicity of inorganic and organic contaminants in a multi-element polluted soil. Environ. Pollut. 158, 2282-2287 (2010)

20. Rowell, D.L.: Soil Science: Methods and Applications, first edn, p. 345. Longman Group, Harlow (1994)

21. Mehra, O.P., Jackson, M.L.: Iron oxide removal from soils and clays by dithionite-citrate systems buffered with sodium bicarbonate. Clays Clay Miner. 7, 317-327 (1960)

22. He, Z., Shentu, J., Yang, X., Baligar, V.C., Zhang, T., Stofella, P.J.: Heavy metal contamination of soils: Sources, indicators, and assessment. J. Environ. Indic. 9, 17-18 (2015)

23. Rollwagen, B.A., Zasoski, R.J.: Nitrogen source effects on rhizosphere $\mathrm{pH}$ and nutrient accumulation by Pacific Northwest conifers. Plant Soil. 105, 79-86 (1988)

24. Cao, H., Chen, J., Zhang, J., Zhang, H., Qiao, L., Men, Y.: Heavy metals in rice and garden vegetables and their potential health risks to inhabitants in the vicinity of an industrial zone in Jiangsu, China. J. Environ. Sci. 22, 1792-1799 (2010) 
25. Mattina, M.J.I., Lannucci-Berger, W., Musante, C., White, J.C.: Concurrent plant uptake of heavy metals and persistent organic pollutants from soil. Environ. Pollut. 124, 375-378 (2003)

26. Muñoz, O., Zamorano, P., Garcia, O., Bastías, J.M.: Arsenic, cadmium, mercury, sodium, and potassium concentrations in common foods and estimated daily intake of the population in Valdivia (Chile) using a total diet study. Food Chem. Toxicol. 109, 1125-1134 (2017)

27. Jalali, M., Mojahed, K.: J.: Assessment of the health risks of heavy metals in soils and vegetables from greenhouse production systems in Iran. Int. J. Phytoremediation 22, 834-848 (2020)

28. ISIRI.: Food and feed-maximum limit of heavy metals. Institute of Standards and Industrial Research of Iran. pp. 210-212 (2010)

29. US-EPA: Integrated risk information system. United States, Environmental Protection Agency (2007). https://www.epa. gov/science-andtechnology/health-science

30. Pajević, S., Arsenov, D., Nikolić, N., Borišev, M., Orčić, D., Župunski, M., Mimica-Dukić, N.: Heavy metal accumulation in vegetable species and health risk assessment in Serbia. Environ. Monit. Assess. 190, 459 (2018)

31. Pietrzak, U., McPhail, D.C.: Copper accumulation, distribution and fractionation in vineyard soils of Victoria, Australia. Geoderma. 122, 151-166 (2004)

32. Lindsay, W.L., Norvell, W.A.: Development of a DTPA soil test for zinc, iron, manganese, and copper. Soil Sci. Soc. Am. J. 42, 421-428 (1978)

33. Tessier, A., Campbell, P.G., Bisson, M.: Sequential extraction procedure for the speciation of particulate trace metals. Anal. Chem. 51, 844-851 (1979)

34. Jaradat, Q.M., Massadeh, A.M., Zaitoun, M.A., Maitah, B.M.: Fractionation and sequential extraction of heavy metals in the soil of scrapyard of discarded vehicles. Environ. Monit. Assess. 112, 197-210 (2006)

35. Kabala, C., Singh, B.R.: Fractionation and mobility of copper, lead, and zinc in soil profiles in the vicinity of a copper smelter. J. Environ. Qual. 30, 485-492 (2001)

36. SAS Institute Inc: SAS Software, Version 9.1 of the SAS System for Windows. SAS Institute Inc, Cary (2004)

37. Hossain, M.K., Strezov, V., Chan, K.Y., Ziolkowski, A., Nelson, P.F.: Influence of pyrolysis temperature on production and nutrient properties of wastewater sludge biochar. J. Environ. Manage. 92, 223-228 (2011)

38. Buss, W., Graham, M.C., Shepherd, J.G., Mašek, O.: Risks and benefits of marginal biomass-derived biochars for plant growth. Sci. Total Environ. 569-570, 496-506 (2016)

39. Song, X.D., Xue, X.Y., Chen, D.Z., He, P.J., Dai, X.H.: Application of biochar from sewage sludge to plant cultivation: Influence of pyrolysis temperature and biochar-to-soil ratio on yield and heavy metal accumulation. Chemosphere. 109, 213-220 (2014)

40. Waqas, M., Li, G., Khan, S., Shamshad, I., Reid, B.J., Qamar, Z., Chao, C.: Application of sewage sludge and sewage sludge biochar to reduce polycyclic aromatic hydrocarbons (PAH) and potentially toxic elements (PTE) accumulation in tomato. Environ. Sci. Pollut. Res. 22, 12114-12123 (2015)

41. Hossain, M.K., Strezov, V., Nelson, P.F.: Comparative assessment of the effect of wastewater sludge biochar on growth, yield and metal bioaccumulation of cherry tomato. Pedosphere. 25, 680-685 (2015)

42. Bose, S., Bhattacharyya, A.K.: Heavy metal accumulation in wheat plant grown in soil amended with industrial sludge. Chemosphere. 70, 1264-1272 (2008)

43. McBride, M.B.: Chemisorption of Cd on calcite surfaces. Soil. Sci. Soc. Am. J. 44, 26-28 (1980) 
44. Bogusz, A., Oleszczuk, P.: Effect of biochar addition to sewage sludge on cadmium, copper and lead speciation in sewage sludge-amended soil. Chemosphere. 239, 124719 (2020)

45. Vaccari, F.P., Maienza, A., Miglietta, F., Baronti, S., Di Lonardo, S., Giagnoni, L., Lagomarsino, A., Pozzi, A., Pusceddu, E., Ranieri, R., Valboa, G., Genesio, L.: Biochar stimulates plant growth but not fruit yield of processing tomato in a fertile soil. Agric. Ecosyst. Environ. 207, 163-170 (2015)

46. Xing, J., Li, L., Li, G., Xu, G.: Feasibility of sludge-based biochar for soil remediation: Characteristics and safety performance of heavy metals influenced by pyrolysis temperatures. Ecotoxicol. Environ. Saf. 180, 457-465 (2019)

47. Ignatowicz, K.: The impact of sewage sludge treatment on the content of selected heavy metals and their fractions. Environ. Res. 156, 19-22 (2017)

48. Huang, R., Zhang, B., Saad, E.M., Ingall, E.D., Tang, Y.: Speciation evolution of zinc and copper during pyrolysis and hydrothermal carbonization treatments of sewage sludges. Water Res. 132, 260-269 (2018)

49. Yuan, H., Lu, T., Huang, H., Zhao, D., Kobayashi, N., Chen, Y.: Influence of pyrolysis temperature on physical and chemical properties of biochar made from sewage sludge. J. Anal. Appl. Pyrolysis. 112, 284-289 (2015)

50. Hemati Matin, N., Jalali, M., Buss, W.: Synergistic immobilization of potentially toxic elements (PTEs) by biochar and nanoparticles in alkaline soil. Chemosphere. 241, 124932 (2020)

\section{Tables}

Table 1. Chemical properties of soil, SS and biochar.

\begin{tabular}{|c|c|c|c|c|c|c|c|c|c|c|c|c|}
\hline \multirow[t]{2}{*}{ Sample } & $\mathrm{pH}$ & $\mathrm{EC}$ & $\mathrm{CaCO}_{3}$ & OM & CEC & $\mathrm{Fe}_{\mathrm{d}}$ & $\begin{array}{l}\text { Total } \\
\text { Cd }\end{array}$ & $\begin{array}{l}\text { Total } \\
\mathrm{Cu}\end{array}$ & $\begin{array}{l}\text { Total } \\
\mathrm{Zn}\end{array}$ & $\begin{array}{l}\text { Cd- } \\
\text { DTPA }\end{array}$ & $\begin{array}{l}\text { Cu- } \\
\text { DTPA }\end{array}$ & $\begin{array}{l}\text { Zn- } \\
\text { DTPA }\end{array}$ \\
\hline & & $\begin{array}{l}\mathrm{dS} \\
\mathrm{m}^{-1}\end{array}$ & $\%$ & & \multicolumn{2}{|c|}{$\mathrm{cmol}_{\mathrm{c}} \mathrm{kg}^{-1}$} & $\underset{1}{\mathrm{~g} \mathrm{~kg}^{-}}$ & \multicolumn{3}{|l|}{$\mathrm{mg} \mathrm{kg}^{-1}$} & \multicolumn{2}{|c|}{$\mathrm{mg} \mathrm{kg}^{-1}$} \\
\hline Soil & 7.4 & 0.14 & 2.7 & 0.4 & 4.8 & 7.67 & 1.04 & 16.4 & 51.8 & 0.03 & 0.23 & 0.43 \\
\hline SS & 6.4 & 2.50 & 10.4 & 29.4 & 43.7 & 7.07 & 1.66 & 161.6 & 570.5 & 0.26 & 24.26 & 122.74 \\
\hline biochar & 6.6 & 1.71 & 10.7 & 12.1 & 5.0 & 3.41 & 1.97 & 173.5 & 732.0 & 0.03 & 0.21 & 16.95 \\
\hline
\end{tabular}

EC: electrical conductivity; $\mathrm{CaCO}_{3}$ : calcium carbonate equivalent; $\mathrm{OM}$ : organic matter; $\mathrm{CEC}$ : cation exchange capacity; $\mathrm{Fe}_{\mathrm{d}}$ : dithionite-citrate-bicarbonate extractable Fe.

Table 2. Bioconcentration factors of PTEs for root $\left(\mathrm{BCF}_{\text {root }}\right)$, shoot $\left(\mathrm{BCF}_{\text {shoot }}\right)$ and fruit $\left(\mathrm{BCF}_{\text {fruit }}\right)$ in tomato plants. 


\begin{tabular}{|c|c|c|c|c|c|c|c|c|c|}
\hline \multirow[t]{2}{*}{ Treatments } & \multirow{2}{*}{$\begin{array}{l}\mathrm{BCF}_{\text {root }} \\
\mathrm{Cd}\end{array}$} & \multicolumn{5}{|l|}{$\mathrm{BCF}_{\text {shoot }}$} & \multicolumn{3}{|l|}{$B C F_{\text {fruit }}$} \\
\hline & & $\mathrm{Cu}$ & $\mathrm{Zn}$ & $\mathrm{Cd}$ & $\mathrm{Cu}$ & $\mathrm{Zn}$ & $\mathrm{Cd}$ & $\mathrm{Cu}$ & $\mathrm{Zn}$ \\
\hline $\mathrm{C}$ & $1.03 \mathrm{c}$ & $0.64 b$ & $1.94 \mathrm{ab}$ & $1.32 b$ & $0.14 \mathrm{c}$ & $1.37 b$ & 0.69 a & $0.21 \mathrm{abc}$ & $0.64 \mathrm{~b}$ \\
\hline $\mathrm{C}+\mathrm{SS} 2$ & $1.46 \mathrm{a}$ & $0.51 b c$ & $1.39 a b$ & $1.28 \mathrm{~b}$ & $0.15 c$ & $1.46 b$ & 0.68 a & $0.21 \mathrm{abc}$ & $1.09 \mathrm{a}$ \\
\hline C+SS5 & $1.47 \mathrm{a}$ & $0.41 b c$ & $1.71 \mathrm{ab}$ & $1.46 \mathrm{~b}$ & $0.23 a b$ & $1.31 b$ & $0.75 \mathrm{a}$ & $0.25 \mathrm{a}$ & $0.71 \mathrm{~b}$ \\
\hline C+SS10 & $1.46 \mathrm{a}$ & $0.44 \mathrm{bc}$ & $2.14 \mathrm{a}$ & $1.67 \mathrm{a}$ & $0.25 \mathrm{a}$ & $1.52 b$ & $0.71 \mathrm{a}$ & $0.23 a b$ & $0.64 \mathrm{~b}$ \\
\hline $\mathrm{C}+\mathrm{B} 2$ & $1.31 \mathrm{~b}$ & $1.11 \mathrm{a}$ & $2.37 \mathrm{a}$ & $1.43 \mathrm{~b}$ & $0.20 \mathrm{~b}$ & $1.93 \mathrm{a}$ & $0.74 \mathrm{a}$ & $0.18 \mathrm{~cd}$ & $0.68 \mathrm{~b}$ \\
\hline $\mathrm{C}+\mathrm{B} 5$ & $1.33 b$ & $1.01 \mathrm{a}$ & $1.96 a b$ & $1.37 \mathrm{~b}$ & $0.14 \mathrm{c}$ & $1.31 \mathrm{~b}$ & $0.73 \mathrm{a}$ & $0.17 \mathrm{bcd}$ & $0.43 \mathrm{c}$ \\
\hline $\mathrm{C}+\mathrm{B} 10$ & $1.27 \mathrm{~b}$ & $0.30 \mathrm{c}$ & $0.78 \mathrm{~b}$ & 1.32 b & $0.06 \mathrm{~d}$ & $0.81 \mathrm{c}$ & $0.75 a$ & $0.13 d$ & $0.38 c$ \\
\hline$S$ & $35.91 x$ & $0.40 z$ & $6.27 x$ & $24.67 x$ & $0.02 x$ & $2.07 x$ & - & - & - \\
\hline$S+B 2$ & $22.09 x$ & 0.59 y & $7.31 x$ & 20.51 y & $0.02 x$ & $1.96 x$ & - & - & - \\
\hline$S+B 5$ & $19.04 x$ & $0.38 z$ & 4.48 y & 17.79 y & $0.02 x$ & 1.49 y & - & - & - \\
\hline$S+B 10$ & $29.22 x$ & $1.26 x$ & $4.95 \mathrm{y}$ & $11.69 \mathrm{z}$ & $0.03 x$ & $1.92 x$ & * & * & * \\
\hline
\end{tabular}

C: non-spiked soil; S: spiked soil; SS: sewage sludge; B: sewage sludge biochar.

Columns marked with the same letter (a-d for non-spiked treatments and $\mathrm{x}-\mathrm{z}$ for spiked treatments) are not significantly different at the $p<0.05$ level.

SS-amended spiked soils not shown because of the no plant growth in these treatments.

- No fruit was grown.

* Of the plants grown in the spiked soil, only S+B10 grew tomato fruits, therefore the treatments are not shown in this table.

Table 3. Estimated daily intake (EDI) $\left(\mathrm{mg} \mathrm{kg}^{-1} \mathrm{day}^{-1}\right)$ and health risk index (HRI) of PTEs via cherry tomato consumption. Of the plants grown in the spiked soil, only $10 \%$ biochar-amended soil grew tomato fruits, therefore the spiked treatments are not shown in this table. 


\begin{tabular}{|c|c|c|c|c|c|c|}
\hline \multirow[b]{2}{*}{ Treatments } & \multicolumn{3}{|c|}{ EDI (mg kg ${ }^{-1}$ day $\left.^{-1}\right)$} & \multicolumn{3}{|l|}{$\mathrm{HRI}$} \\
\hline & $\mathrm{Cd}$ & $\mathrm{Cu}$ & $\mathrm{Zn}$ & $\mathrm{Cd}$ & $\mathrm{Cu}$ & $\mathrm{Zn}$ \\
\hline \multicolumn{7}{|l|}{ Adult } \\
\hline C & 0.00011 & 0.00051 & 0.00425 & 0.106 & 0.013 & 0.014 \\
\hline SS2 & 0.00012 & 0.00086 & 0.00831 & 0.126 & 0.021 & 0.028 \\
\hline SS5 & 0.00013 & 0.00104 & 0.00901 & 0.140 & 0.026 & 0.030 \\
\hline SS10 & 0.00013 & 0.00105 & 0.00918 & 0.132 & 0.026 & 0.031 \\
\hline B2 & 0.00013 & 0.00065 & 0.00555 & 0.133 & 0.016 & 0.018 \\
\hline B5 & 0.00011 & 0.00069 & 0.00548 & 0.131 & 0.017 & 0.018 \\
\hline B10 & 0.00012 & 0.00067 & 0.00615 & 0.129 & 0.017 & 0.020 \\
\hline \multicolumn{7}{|l|}{ Children } \\
\hline C & 0.00023 & 0.00109 & 0.00913 & 0.229 & 0.027 & 0.030 \\
\hline SS2 & 0.00027 & 0.00185 & 0.01786 & 0.272 & 0.046 & 0.059 \\
\hline SS5 & 0.00030 & 0.00223 & 0.01936 & 0.300 & 0.056 & 0.064 \\
\hline SS10 & 0.00028 & 0.00225 & 0.01973 & 0.283 & 0.056 & 0.066 \\
\hline B2 & 0.00028 & 0.00140 & 0.01923 & 0.285 & 0.035 & 0.040 \\
\hline B5 & 0.00028 & 0.00149 & 0.01177 & 0.282 & 0.037 & 0.039 \\
\hline B10 & 0.00029 & 0.00144 & 0.01322 & 0.278 & 0.036 & 0.044 \\
\hline
\end{tabular}

C: control soil; SS: sewage sludge; B: sewage sludge biochar.

Spiked treatments were not analyzed because they had not borne fruit.

\section{Figures}


(a)

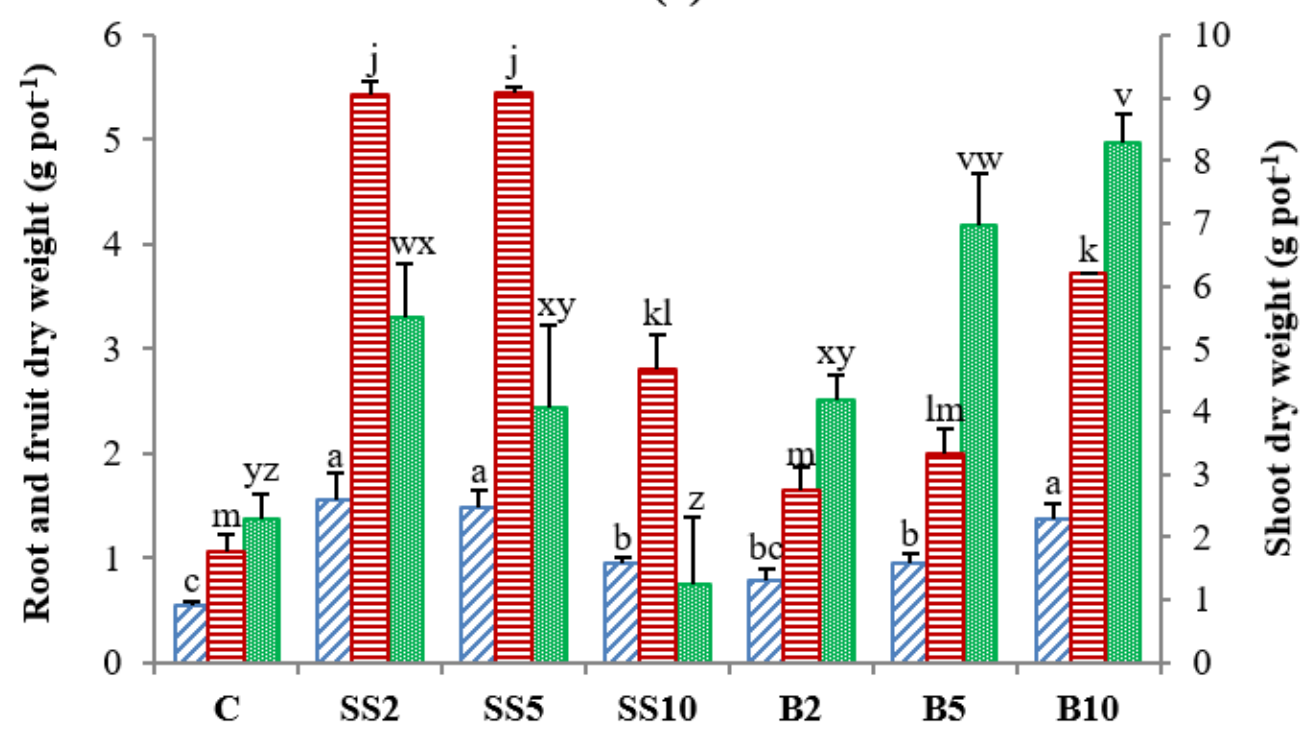

$\oslash$ Root $\quad$ Fruit $\quad$ 目 Shoot

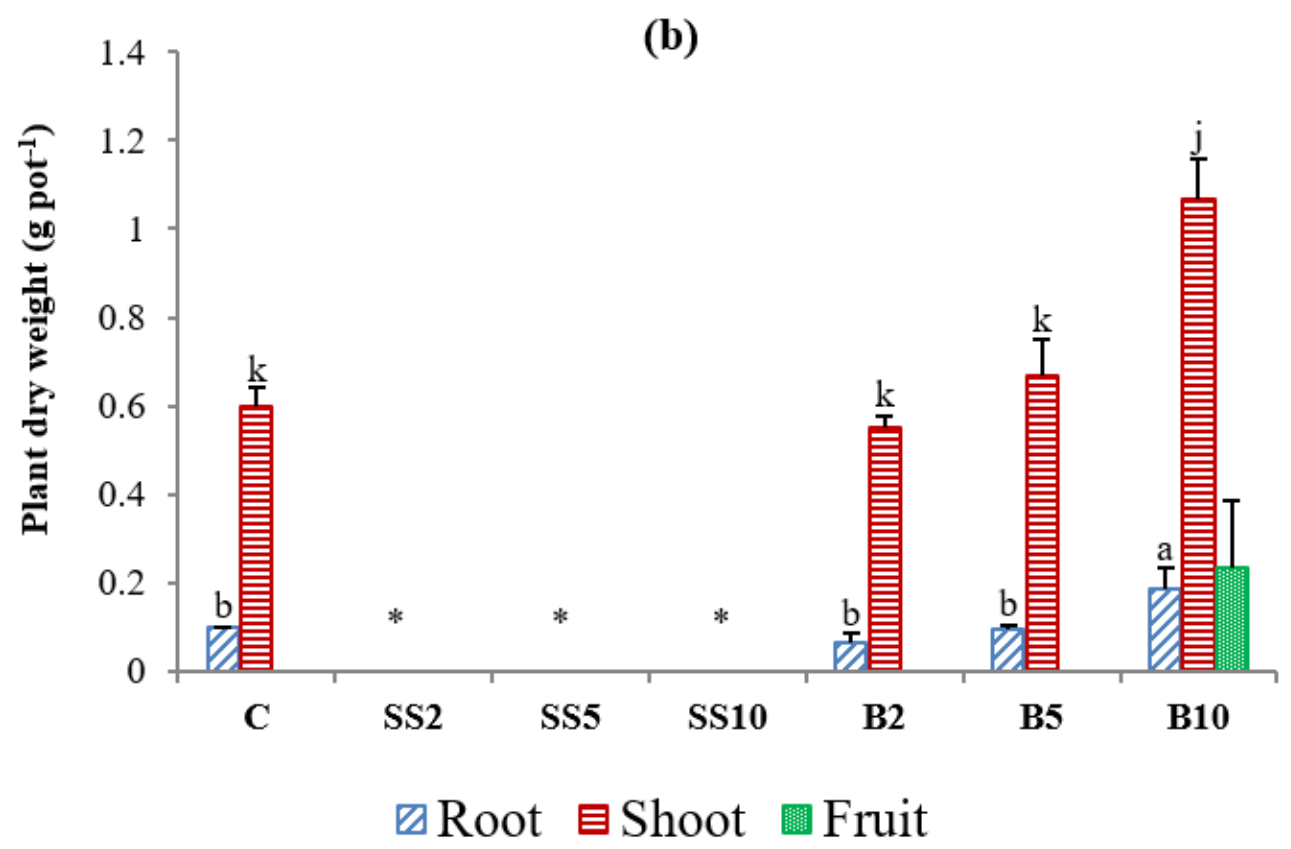

Figure 1

Root, shoot and fruit dry weight (g pot-1) of tomato plants grown in non-spiked (a) and spiked (b) soil. C: control soil; SS: sewage sludge; B: sewage sludge biochar. Columns marked with the same letter (a-c for root, $j-m$ for shoot and $\mathrm{v}-\mathrm{z}$ for fruit) are not significantly different (Duncan's multiple range test) at the $\mathrm{p}<0.05$ level. Error bars represent standard deviations $(n=3)$. * marks the treatments that were so severely affected that no plant biomass could be measured. 

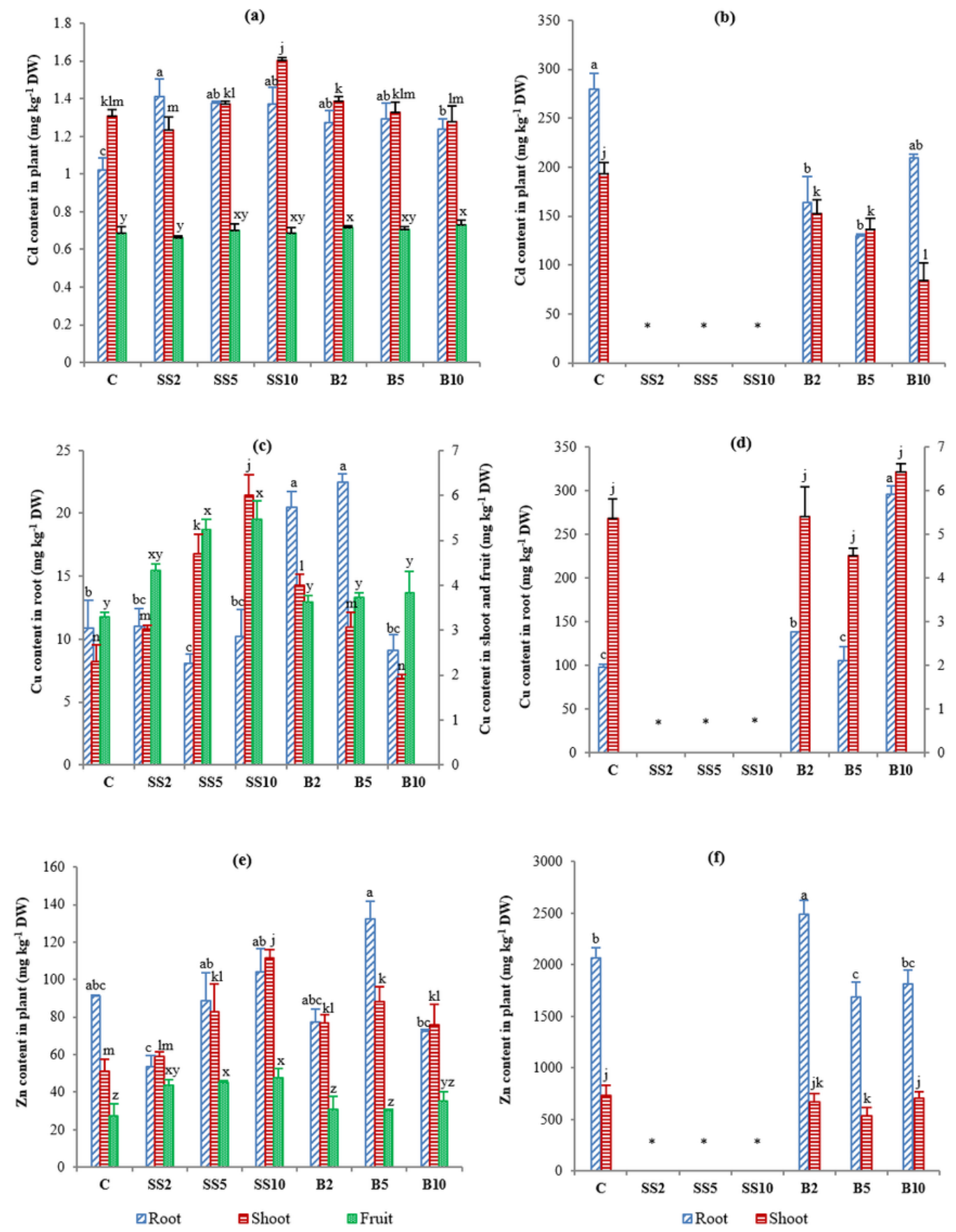

Figure 2

Effect of SS and SS biochar on Cd, Cu and Zn contents in root, shoot and fruit of non-spiked (a, c and e) and spiked soil ( $b, d$ and f). C: control soil; SS: sewage sludge; B: sewage sludge biochar. Columns marked with the same letter (a-c for root, $\mathrm{j}-\mathrm{n}$ for shoot and $\mathrm{x}-\mathrm{z}$ for fruit) are not significantly different (Duncan's multiple range test) at the $p<0.05$ level. Error bars represent standard deviations $(n=3) . *$ marks the treatments that were so severely affected that no plant biomass could be measured. 

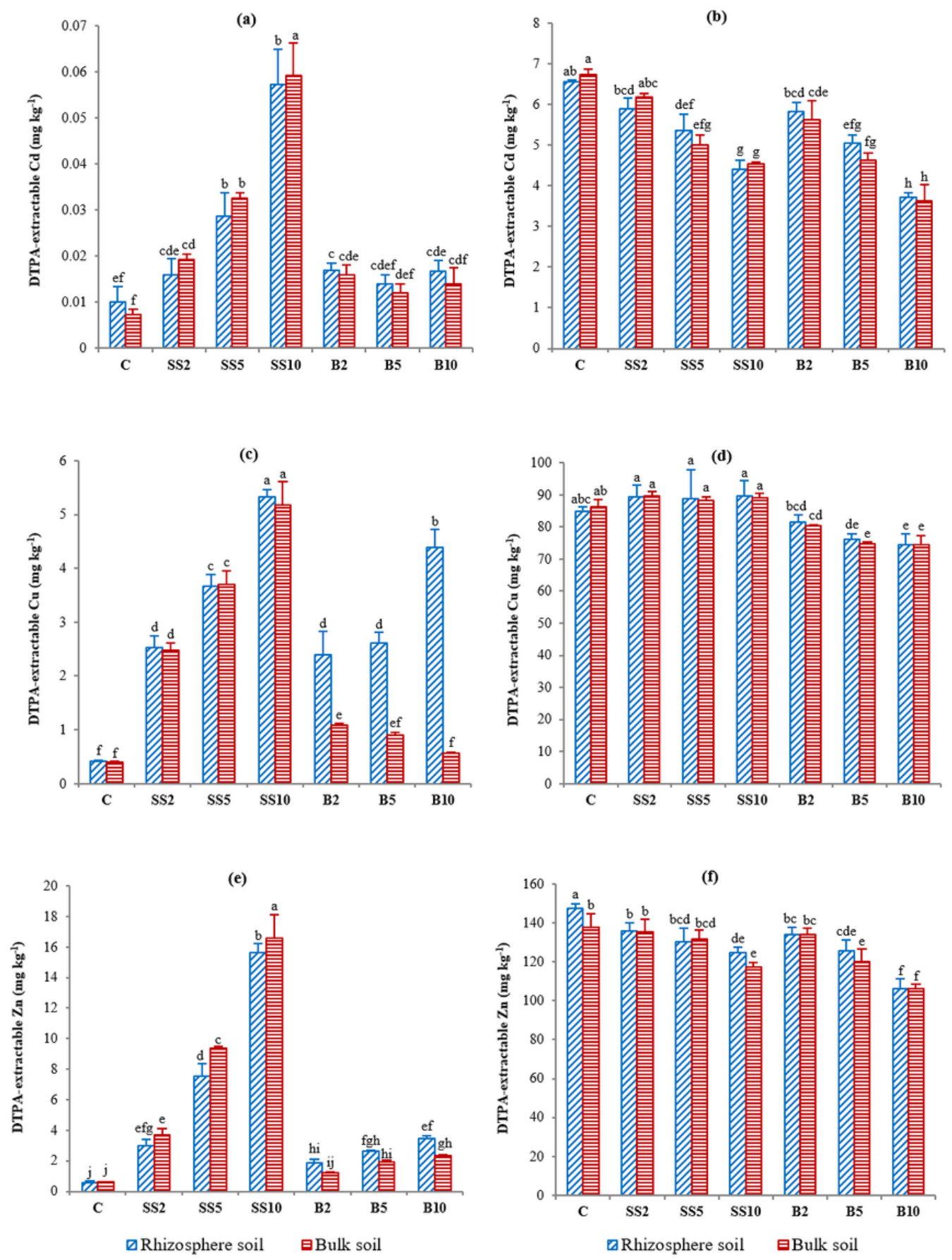

Figure 3

DTPA-extractable PTE contents in non-spiked ( $a, c$ and e) and spiked soils (b, $d$ and f). C: control soil; SS: sewage sludge; B: sewage sludge biochar. Columns marked with the same letter are not significantly different (Duncan's multiple range test) at the $p<0.05$ level. Error bars represent standard deviations $(n=3)$. 
(a)

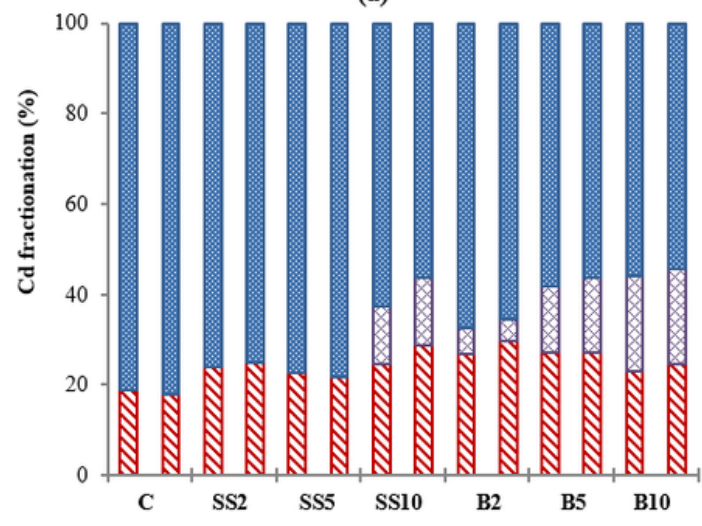

(c)

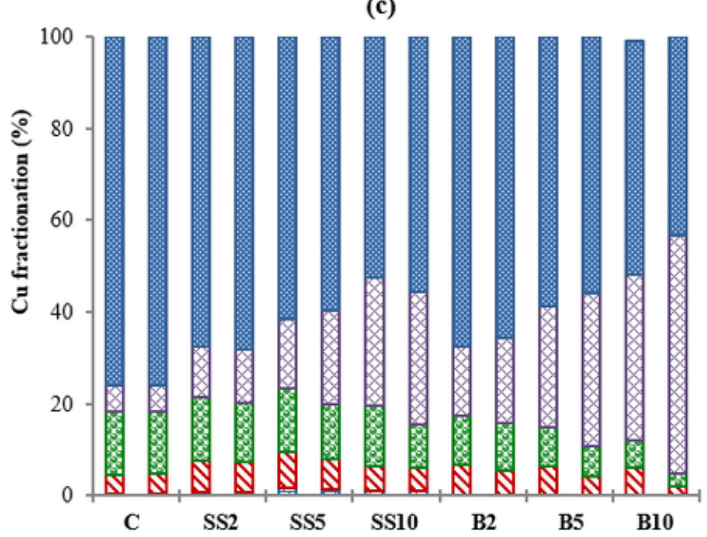

(e)

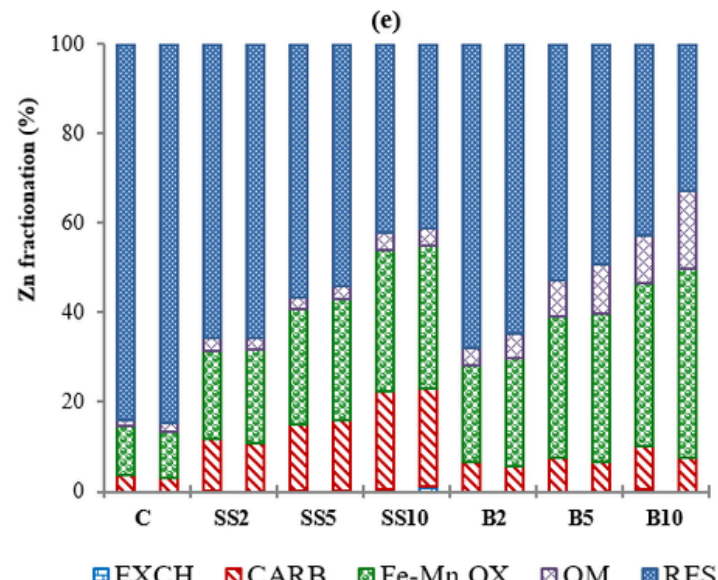

(b)

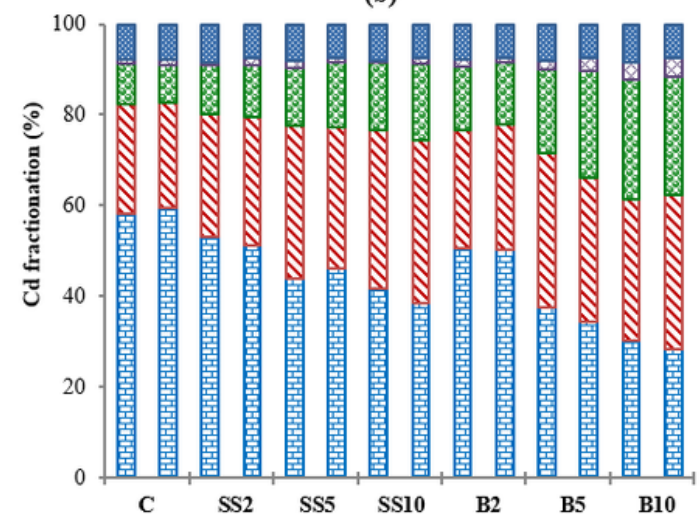

(d)

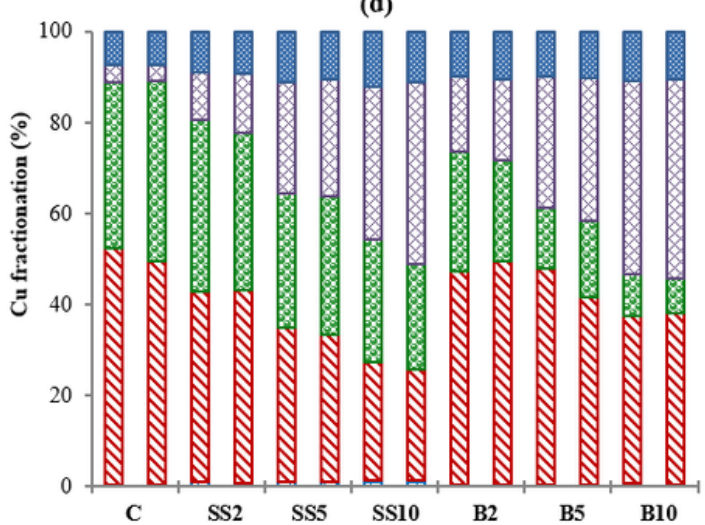

(f)

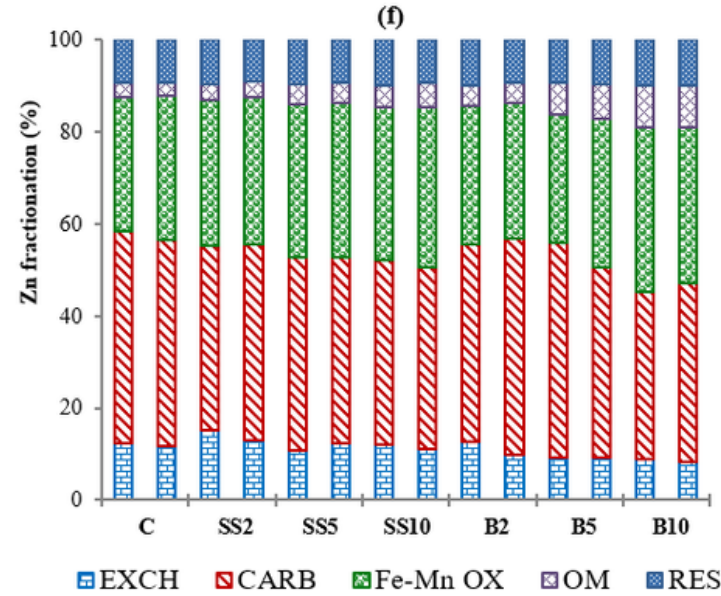

Figure 4

Chemical fractionation of PTEs in rhizosphere soils (left columns in each figure) and bulk soils (right columns) in non-spiked ( $a, c$ and $e$ ) and spiked soils (b, $d$ and $f)$. Statistically significant differences among treatment means were identified for each fraction but results are not shown. For non-spiked treatments, the contents of $\mathrm{Cd}$ in $\mathrm{EXCH}$ and Fe-Mn OX fractions as well as some treatments in OM fraction were below the detection limit of AAS. C: control soil; SS: sewage sludge; B: sewage sludge biochar. 
This is a list of supplementary files associated with this preprint. Click to download.

- Appendix.docx

- Graphicabstract.docx 